\title{
The Effect of Zinc-Proteinate Supplementation on the In Vitro Digestibility and Ruminal Fermentation in Goat
}

\author{
Gilbert Nathaniel, Tiara Annisa, Anis Muktiani*, Dian Wahyu Harjanti and Widiyanto \\ Faculty of Animal and Agricultural Sciences, Diponegoro University, Semarang, Central Java 50275, Indonesia \\ *Corresponding author email: anismuktiani@lecturer.undip.ac.id
}

\begin{abstract}
This study aimed primarily to investigate the effect of Zn-Proteinate (Zn-Prot) supplementation on in vitro rumen digestibility and rumen fermentation. This research used a completely randomized design with four treatments and four replicates. The experimental treatment was the supplementation of various levels of Zn-Prot ( $0 ; 12.5 \mathrm{ppm} ; 25 \mathrm{ppm}$, and $37.5 \mathrm{ppm})$ on a dry matter basis. Parameters determined were in vitro dry matter digestibility (IVDMD), in vitro organic matter digestibility (IVOMD), partial volatile fatty acid (VFA) (acetate, propionate, and butyrate), $\mathrm{A} / \mathrm{P}$ ratio, $\mathrm{CH} 4$, and the efficiency of the conversion hexose to VFA. Data were analyzed using ANOVA. The results showed that goats fed with a diet supplemented with $25 \mathrm{ppm} \mathrm{Zn}$-Prot had the highest IVDMD and IVOMD values. There was no significant effect on the VFA and $\mathrm{CH} 4$ concentrations, $\mathrm{A} / \mathrm{P}$ ratio, and the efficiency of the hexose-VFA conversion within treatment groups. In conclusion, supplementing $25 \mathrm{ppm}$ of $\mathrm{Zn}$-Prot into the diet of dairy goat increase the dry matter and organic matter digestibility.
\end{abstract}

Keywords: zinc-proteinate, digestibility, rumen fermentation, in vitro, goat

Abstrak. Penelitian ini bertujuan untuk melihat pengaruh dari suplementasi Zn-proteinat (Zn-Prot) terhadap kecernaan dan fermentabilitas rumen secara in vitro. Rancangan percobaan pada penelitian ini yaitu rancangan acak lengkap (RAL) dengan empat perlakuan dan empat ulangan. Suplementasi $\mathrm{Zn}$-Prot yang di berikan yaitu 0 (tanpa supplementasi), 12,5 ppm, $25 \mathrm{ppm}$ dan 37,5 ppm. Parameter pada penelitian ini meliputi kecernaan bahan kering (KCBK), kecernaan bahan organik (KCBO), volatile fatty acid (VFA) parsial (asetat, propionat dan butirat), rasio $\mathrm{A} / \mathrm{P}, \mathrm{CH}_{4}$ dan efisiensi konversi heksosa menjadi VFA. Analisis data yang di gunakan yaitu ANOVA. Hasil penelitian ini menunjukan bahwa pemberian suplementasi Zn-Prot dengan level 25 ppm menghasilkan nilai kecernaan bahan kering (KCBK) dan kercernaan bahan organik (KCBO) tertinggi sedangkan suplementasi Zn-Prot tidak berpengaruh terhadap parameter VFA parsial, rasio $A / P, C_{4}$ dan efisiensi konversi heksosa menjadi VFA. Dari hasil penelitian yang di peroleh dapat di simpulkan bahwa suplementasi Zn-Prot dengan taraf $25 \mathrm{ppm}$ pada kambing perah dapat meningkatkan kecernaan bahan kering (КСBK) dan kecernaan bahan organik (КСBO).

Kata kunci: Zinc-proteinat, kecernaan, fermentabilitas rumen, in vitro, kambing

\section{Introduction}

Feed management is one of the factors that significantly impact animal husbandry, especially ruminants. Feed-in ruminants consist of fibrous feed that provides energy for ruminants (Widodo et al., 2012); therefore, the fiber digestion process is vital for ruminants, especially in Indonesia. Some feed ingredients in Indonesia, especially in smallholder farms, still contain agricultural waste dominated by fiber content. Fiber digestion in ruminants is greatly influenced by feed composition, lignin content, cellulose content, the activity of fibrinolytic, cellulolytic microorganisms, and microbial protein synthesis (Pathak, 2008;
Noziére et al., 2010; Ransa et al., 2020; Hambakodu et al., 2020). Another factor that impacts fiber digestion in the rumen is the sufficiency of mineral zinc (Zn) (Wang et al., 2013; Arelovich et al., 2014; Hartati et al., 2020).

Mineral $\mathrm{Zn}$ is known as a multi-functional micro mineral, such as the co-factor of 300 enzymes, protein and DNA synthesis, and metabolism of essential fatty acid (Elamin et al., 2013; Aliarabi et al., 2015). Zn minerals in rumen microbial growth are due to their function as a metalloenzyme that plays volatile roles in carboxypeptidase $A$ and $B$ enzymes and alkaline phosphatase, which significantly 
contribute to protein digestion and protein synthesis, including microbial protein synthesis (Hartati et al., 2020). Increased microbial protein synthesis will impact the increase of total rumen microbes, especially cellulolytic bacteria, thus increasing the efficiency of digestion of fibrous feed as well as the final product (acetate, propionate, and butyrate) (Noziére et al., 2010; Suhendra et al., 2015; Ransa et al., 2020). Increased digestibility of fibrous feed will improve energy availability for body metabolism, and hence, increase livestock productivity. The common problem in Indonesia is the very low mineral content in the feed. Suhada et al. (2012) stated that the mineral content of $\mathrm{Zn}$ in elephant grass, bagasse, and sugar cane shoot ranges between 4 and $8 \mathrm{ppm}$. also, the mineral content of feed ingredients is strongly influenced by season (Fariani, 2008).

According to NRC (1981), the requirement of $\mathrm{Zn}$ for dairy goats is estimated at $10 \mathrm{ppm} /$ day relative to the type, breed, and physiological status. Supplementing $20 \mathrm{ppm} \mathrm{Zn} \mathrm{peptide} \mathrm{to}$ Zandi lambs increased in vitro dry matter digestibility (IVDMD) and neutral detergent fiber (NDF) digestibility (Mallaki et al., 2015), while $30 \mathrm{ppm} \mathrm{Zn}$ methionine supplemented to Muzaffarnagri lambs have increased acids detergent fiber (ADF) digestibility (Grag et al., 2008). It shows differences in the requirement of $\mathrm{Zn}$ mineral in each breed of livestock. In addition to the level of supplementation, the form of $\mathrm{Zn}$ contributes significantly to the level of effectiveness. Zinc mineral in organic form (Zn-Prot) is more effective than inorganic form (ZnSO4) (Muktiani and Prastiwi, 2014). Mineral in the organic form is the process of chelating dissolved metal slats with hydrolyzed amino acids or proteins, so they further assist the activity of enzymes in the rumen (Supriyati et al., 2000). The purpose of this research is to investigate the effect of $\mathrm{Zn}$ mineral (Zn-Prot) supplementation at various levels on rumen digestibility as well as rumen fermentation.

\section{Materials and Methods}

This research has conducted within June August 2020 at the Laboratory of Animal Nutrition, Faculty of Animal and Agricultural Sciences, Diponegoro University, Semarang.

The research was conducted using a completely randomized design with four treatments and four replications. The experimental treatment was the supplementation of basal diets with various levels of Zn-Prot (0 ppm, 12.5 ppm, 25 ppm, and $37.5 \mathrm{ppm}$ ) on a dry matter basis. The materials used in this research are goat rumen fluid, McDougall's solution, CO2, centrifuge, shaker bath, fermentor tube, ventilated rubber cap, ash-free filter paper (Whatman no. 41), exicator, vacuum pump, porcelain cup, oven, electric furnace, and $\mathrm{Zn}$-Prot. The basal diet consisted of concentrate, soybean husk, dried kale, odot grass (Pennisetum purpureum cv. Mott), calliandra (Calliandra calothyrsus), and Indigofera (Indigofera tinctoria). The composition and nutrient content of the concentrate and basal diet in this research are presented in Table 1 and Table 2.

Goat rumen fluid was collected from Ettawah Crossbreed goat through slaughtering and incubated at $38^{\circ}-39^{\circ} \mathrm{C}$. The in vitro process was carried out by mixing basal diet $(0,56 \mathrm{~g}), \mathrm{Zn}$-Prot, McDougall solution $(40 \mathrm{ml})$, and rumen fluid $(10 \mathrm{ml})$ into a fermentor tube and added with $\mathrm{CO} 2$ for $10-20$ seconds, then sealed with a ventilated rubber cap. In the next step, the fermentor tube was incubated in a water bath at $39^{\circ}-40^{\circ} \mathrm{C}$. For the partial VFA parameter, the incubation was carried out for 4 hours after then the fermentation process was halted with ice cubes, and then the samples were centrifuged for 10 minutes at 10.000 RPM to take the liquid (supernatant). Partial VFA measurements based on AOAC (1975) using Shimadzu series GC-2010 plus gas chromatography made in Japan. 
Table 1. Nutritional composition of concentrate

\begin{tabular}{lccccccc}
\hline \multirow{2}{*}{ Feed ingredients } & Composition & CP & Ash & CF & EE & NFE & TDN \\
\cline { 2 - 8 } & \multicolumn{7}{c}{$\%$} \\
\hline Soybean meal & 17.61 & 6.66 & 3.12 & 1.16 & 0.51 & 6.16 & 12.86 \\
DDGS & 14.79 & 4.33 & 0.91 & 1.58 & 1.18 & 6.79 & 12.31 \\
Copra & 8.71 & 1.71 & 0.62 & 3.77 & 1.00 & 1.62 & 4.72 \\
Rice bran & 13.90 & 1.35 & 2.60 & 4.98 & 0.61 & 4.37 & 7.27 \\
Soybean husk & 14.79 & 2.40 & 0.96 & 6.38 & 0.90 & 4.16 & 7.35 \\
Wheat bran & 30.19 & 5.42 & 1.19 & 1.81 & 2.00 & 19.77 & 26.14 \\
\hline Total & 100 & 21.86 & 9.40 & 19.68 & 6.19 & 42.87 & 70.65 \\
\hline
\end{tabular}

$\mathrm{CP}=$ crude protein, $\mathrm{CF}=$ crude fiber, $\mathrm{EE}=$ ether extract, $\mathrm{NFE}=$ nitrogen free extract dan TDN = total digestible nutrient, DDGS = distiller's dried grain with soluble, ND = not detected.

Table 2. Nutritional composition of experimental diet (100\% DM)

\begin{tabular}{|c|c|c|c|c|c|c|c|c|c|c|}
\hline \multirow{2}{*}{ Feed Ingredients } & Composition & $\mathrm{CP}$ & Ash & $\mathrm{CF}$ & $\mathrm{EE}$ & NFE & TDN & NDF & ADF & $\mathrm{Zn}$ \\
\hline & \multicolumn{9}{|c|}{$\%$} & Ppm \\
\hline P. purpureum & 7.61 & 1.27 & 1.11 & 2.89 & 0.31 & 2.03 & 3.93 & 4.55 & 2.92 & 1.12 \\
\hline Indigofera tinctoria & 1.56 & 0.39 & 0.17 & 0.15 & 0.03 & 0.81 & 1.19 & 0.29 & 0.24 & ND \\
\hline Calliandra & 2.52 & 0.49 & 0.14 & 0.27 & 0.01 & 1.61 & 1.89 & 0.59 & 0.50 & 0.18 \\
\hline Soybean husk & 31.20 & 5.07 & 2.02 & 13.46 & 1.90 & 8.76 & 15.49 & 18.96 & 13.12 & 1.58 \\
\hline Dried Kale & 29.64 & 2.46 & 3.47 & 6,44 & 0.57 & 16.70 & 18.70 & 12.45 & 11.17 & ND \\
\hline Concentrate & 27.47 & 6.01 & 2.58 & 5.41 & 1.70 & 11.78 & 19.41 & 10.78 & 5.06 & 9.44 \\
\hline Total & 100 & 15.69 & 9.49 & 28.62 & 4.52 & 41.69 & 60.61 & 46.23 & 33.01 & 12.32 \\
\hline
\end{tabular}

The measurement procedure was performed by injecting $1 \mu \mathrm{l}$ of supernatant sample into the gas chromatography, then the column reduction will be captured by a computer recorder for producing a graph and is calculated by the formula. Parameters such as $\mathrm{CH} 4$ and the efficiency of the conversion hexose energy to VFA were measured using the estimated individual VFA calculation based on Ørskov and Ryle's (1990) formula.

In vitro dry matter digestibility (IVDMD) and in vitro organic matter digestibility (IVOMD) incubation was carried out for $96 \mathrm{~h}$. The first 48$h$ incubation constituted fermentative digestion, and the next $48 \mathrm{~h}$ was enzymatic digestion. During the incubation, the fermentor tube was shaken every 6 hours. After the fermentative digestion process, the samples were centrifuged for 10 minutes at 10.000 RPM to separate solid and liquid (supernatant). Then the solid was returned to the fermentor tube, added with $50 \mathrm{ml}$ pepsin $\mathrm{HCl}$, and incubated for 48 hours in the water bath at a temperature of $39^{\circ}-40^{\circ}$ C. After the enzymatic digestion process was completed, the sample was filtered using an ash-free filter paper then oven-dried for $24 \mathrm{~h}$ at $105^{\circ} \mathrm{C}$. After being removed from the oven, the sample was incorporated into the exicator for 30 minutes before weighing. The last process was placing the sample into the furnace for 6 hours at $400^{\circ} \mathrm{C}$ and weighing. In vitro dry matter digestibility (IVDMD) and in vitro organic matter digestibility (IVOMD) value was calculated based on Tilley and Terry (1963) equation:

$\operatorname{IVDMD}(\%)=\frac{\text { Initial dry matter input }-(\text { residue-blanko })}{\text { Initial dry matter input }} \times 100 \%$

$\operatorname{IVOMD}(\%)=\frac{\text { Initial organic matter input-(residue-blanko) }}{\text { Initial organic matter input }} \times 100 \%$

The data obtained were analyzed using ANOVA (analysis of variance) in a Completely Randomized Design with a significant level of $5 \%$ and continued with the Duncan's Multiple Range test (Steel and Torrie, 1994). 


\section{Results and Discussion}

The results of Zn-Prot supplementation on feed digestibility in Figure 1 show a significant difference of IVDMD and IVOMD value across $(P<0,05)$ between treatments. The highest IVDMD and IVOMD values in this research are in 25 ppm treatment with $68,99 \%$ and $84,51 \%$ (Figure 1). The high digestibility of dry matter and organic matter value represents the higher the nutritional value opportunity to be absorbed. The increase of dry matter and organic matter digestibility value is due to the function of mineral $\mathrm{Zn}$, such as the synthesis of protein, DNA, and nucleic acids, as well as the of >300 enzymes and microbial growth factor (Krisnan et al., 2009; Elamin et al., 2013; Aliarabi et al., 2015). The influence of the mineral $\mathrm{Zn}$ on protein, DNA, and nucleic acid synthesis is inseparable from their influence on DNA and RNA polymerase activity (Putra., 2006). In addition, the mineral $\mathrm{Zn}$ also acts as metalloenzymes which play a broad role in the carboxylation enzymes of peptidase $A \& B$ and alkaline phosphate (Hartati et al., 2020). As a result, enzyme activity in rumen bacteria increases, more microbial proteins are synthesized, eventually improving the growth rate of rumen bacteria (Putra., 2006; Krisnan et al., 2009; Hilal et al., 2016). An increase in the microbial growth rate will directly impact the

b

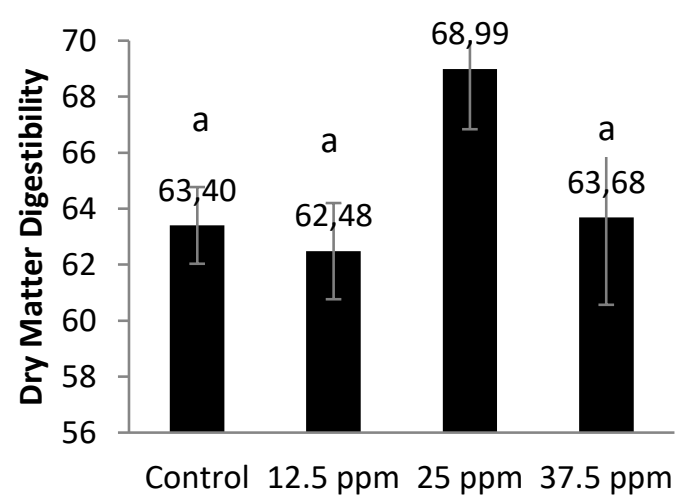

efficiency of feed digestibility, particularly fibrous feed, thus an increased absorbability (Noziére et al., 2010; Ransa et al., 2020).

The results of rumen fermentability in this research show no significant differences between treatments (Table 4). The different result between digestibility and product fermentability was indicative of zero effect of Zn supplementation at $12.5-37.5 \mathrm{ppm}$ on the proportion and number of rumen microbe. The value of individual VFA value is significantly influenced by the proportion and number of rumen microbe, particularly especially cellulolytic, proteolytic, and amylolytic bacteria (Yurleni et al.,2013). Hungate (1966) stated that the requirement of $\mathrm{Zn}$ for rumen microbes is within $130-220 \mathrm{ppm}$. The same result was obtained by Hosseini-Vardanjani et al. (2020), where there was no influence $\mathrm{Zn}$ supplementation at $30 \mathrm{ppm}$ against individual VFA values although dry matter digestibility increase. This result was indicated due to changes in the rumen fermentation process in the capture of feed energy as VFA (Bateman et al., 2004; Hosseini-Vardanjani et al.,2020). Meanwhile, the proportion of acetate in this research is higher than the standard value $(73-$ $74 \%)$. Butyrate proportion in this study (6\%) was lower than the normal range, as reported by Bregman et al. (1965), i.e., $64-70 \%, 17-$ $21 \%$, and $12-15 \%$.

\section{b}

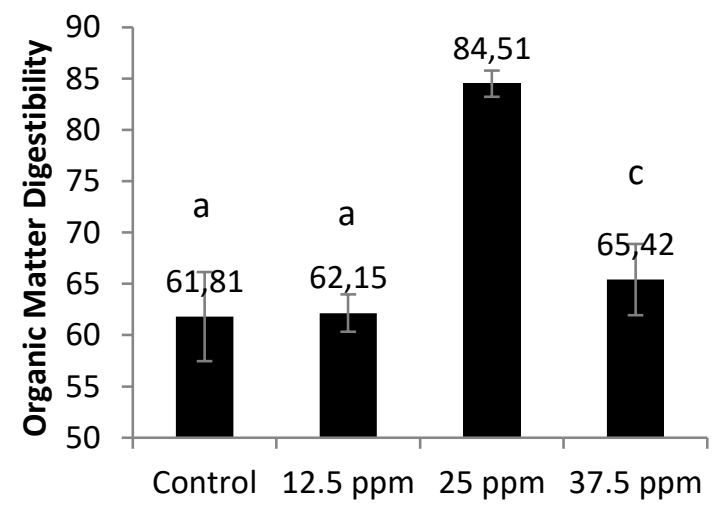

Figure 1. The effect of zn-proteinate supplementation on dry matter and organic matter digestibility (Different superscript in same table shows significant different $p<0.05$ ). 
Table 4. The Effects of Zn-Proteinate on Rumen Fermentation

\begin{tabular}{|c|c|c|c|c|c|}
\hline \multirow{2}{*}{ Parameter } & \multicolumn{4}{|c|}{ Zn-Proteinate levels (ppm) } & \multirow[t]{2}{*}{ SEM } \\
\hline & 0 & 12.5 & 25 & 37.5 & \\
\hline Acetate (mM) & 15.14 & 16.33 & 19.83 & 14.50 & 0.855 \\
\hline Proportion of acetate (\%) & 74.91 & 73.34 & 74.65 & 75.92 & 0.22 \\
\hline Propionate (mM) & 3.80 & 4.50 & 5.05 & 3.51 & 0.278 \\
\hline Proportion of propionate (\%) & 18.62 & 20.01 & 19.02 & 18.05 & 0.23 \\
\hline Butyrate (mM) & 1.31 & 1.50 & 1.69 & 1.17 & 0.097 \\
\hline Proportion of butyrate (\%) & 6.47 & 6.65 & 6.32 & 6.03 & 0.38 \\
\hline A/P Ratio & 4.04 & 3.68 & 3.93 & 4.24 & 0.095 \\
\hline $\mathrm{CH}_{4}(\mathrm{mM})$ & 7.27 & 7.79 & 9.50 & 6.90 & 0.423 \\
\hline $\begin{array}{l}\text { The Efficiency of the } \\
\text { Conversion Hexose to VFA (\%) }\end{array}$ & 72.34 & 72.99 & 72.49 & 71.95 & 0.168 \\
\hline
\end{tabular}

SEM (Standard error of the mean).

The value of the $A / P$ ratio in this research was $3.68-4.24$ or higher than reported by Muktiani et al. (2019). The A/P, which illustrates the efficiency of energy utilization in ruminants (Rahayu et al., 2018), is strongly influenced by fiber and non-structural carbohydrates digestion (Purbowati et al., 2014; Puastuti et al., 2010).

Therefore, the higher the $A / P$ value, the higher the acetate concentration, thus increasing $\mathrm{CH} 4$ and decreasing energy efficiency. While the value of $\mathrm{CH} 4$ in this research was $6.90-9.50 \mathrm{mM}$, Petriĉ et al., (2021) reported that supplementing $70 \mathrm{ppm} \mathrm{Zn}$ mineral in the diet produced $1.74-2.80 \mathrm{mM}$ of $\mathrm{CH} 4$. According to Ekawati et al. (2015), the value of $\mathrm{CH} 4$ in sheep that consume diets containing $25 \%$ crude fiber and $13 \%$ crude protein is $9.11 \mathrm{mM}$.

The values of $\mathrm{CH} 4$ are highly varied, depending on the digestibility of fiber in the diet (Imanda et al., 2016). The higher the fiber digestibility, the higher the acetate and butyrate value, as well as the number of hydrogen gas (H2) (Puniya et al., 2015). Hydrogen gas $(\mathrm{H} 2)$ is the raw material for methanogenesis, so the increase of $\mathrm{CH}_{4}$ is parallel to H2 (Hapsari et al., 2018; Susilo et al., 2019). The higher $A / P$ ratio and $C H 4$ values will impact decreasing energy efficiency (Muktiani et al., 2019). In this research, the value of efficiency hexose conversion to VFA (71-72\%) was not affected by $\mathrm{Zn}$ supplementation. This result was higher than the $70 \%$ by Wahyuni et al. (2014) but lower than the $77 \%$ by Muktiani et al. (2019). The high variation in conversion efficiency of hexose to VFA depends on individual VFA values, particularly propionate (Ørskov and Ryle 1990; Faizah et al., 2019).

\section{Conclusions}

The supplementation of $25 \mathrm{ppm} \mathrm{Zn}$-Prot into the diet of dairy goat increased the dry matter and organic matter digestibility.

\section{References}

Aliarabi, H, A Fadayifar, MM Tabatabaei, P Zamani, A Bahari, A Farahavar, and AH Dezfoulian. 2015. Effect of zinc source on hematological, metabolic parameters and mineral balance in Lambs. Biologycal Trace Element Research, 168(1): 82 90.

Arelovich, HM, MI Amela, MF Martínez, RD Bravo, and MB Torrea. 2014. Influence of different sources of zinc and protein supplementation on digestion and rumen fermentation parameters in sheep consuming low-quality hay. Small Ruminants Research, 121: 175 - 182.

AOAC. 1975. Official Methods of Analysis. 12th. Ed. Association of Official Analytical Chemistry, Washington, D. C.

Bateman, HG, CC Williams, DT Gantt, YH Chung, AE Beem, CC Stanley, GE Goodier, PG Hoyt, JD Ward, and LD Bunting. Effect of zinc and sodium monensin on ruminal degradation of lysine- $\mathrm{HCL}$ and liquid 2-hydroxy-4-methylthiobutanoic acid. Journal of Dairy Sciences, 87(8): 2571 - 2577.

Bregman, EN, RS Reid, MG Murray, JM Brockway, and FG Whitelaw. 1965. Interconversions and production of volatile fatty acids in the sheep rumen. Biochem. J. 97: 53-58. 
Cope, CM, AM Mackenzie, D Wilde, and LA Sinclair. 2009. Effects of level and form of dietary zinc on dairy cow performance and health. Journal of Dairy Sciences, 92: $2128-2135$.

Elamin, KM, NA Dafalla, KA Abdel Atti, and AA Tameen Eldar. 2013. Effect of zinc supplementation on growth performance and some blood parameters of goats kids in Sudan. International Journal of Pure and Applied Biological Research and Sciences, 1(1): $1-8$.

Ekawati, W, A Muktiani, and Sunarso. 2015. Pengaruh penggunaan starter Lactobacillus plantarum pada silase ransum komplit berbahan enceng gondok terhadap VFA parsial, produksi gas metan dan glukosa darah domba. Jurnal IImu Ternak danVeteriner 4(1): $1-6$.

Fariani, A. 2008. Micro mineral distribution on fiber fraction of forages in South Sumatra, Indonesia Journal of Indonesia Tropica Animal Agriculture, 33(1):79-86.

Faizah, LI, W Widiyanto, and A Muktiani. 2019. The effect of total or partial protected vegetable oil supplementation on in vitro digestibility, feed fermentability and energy efficiency. Bulletin of Animal Science, 43(3): 171 - 178.

Fellner, V, S Durosoy, V Kromm, and JW Spears, PAS 2021. Effects of supplemental zinc on ruminal fermentation in continuous cultures. Applied Animal Sciences, 37(1): $27-32$.

Grag, AK, V Mudgal, and RS Dass. 2008. Effect of organic zinc supplementation on growth, nutrient utilization and mineral profile in lambs. Animal Feed Science and Technology 144(1-2): $82-96$.

Habeeb, AAM, AA El-Tarabany, and AE Gad. 2013. Effect of zinc levels in diets of goat on reproductive efficiency, hormonal levels, milk yield, and growth aspects of their kids. Global Veterinaria, 10(5): $556-564$.

Hassan, AH, GM El Ashry, and SM Soliman. 2011. Effect of supplementation of chelated zinc on milk production on ewes. Food and Nutrition Science, 2: $706-713$.

Hapsari, SN, DW Harjanti, and A Muktiani. 2018. Fermentabilitas pakan dengan imbuhan ekstrak daun Babadotan (Ageratum conyzoides) dan Jahe (Zingiber officinale) pada sapi perah secara in vitro. Agripet, 18(1): 1 - 9.

Hartati, E, A Saleh, ED Sulistijo, G Oematan, I Benu, and YL Henuk. 2020. Increasing propionate acid production in Bali Cattle through $\mathrm{ZnSO}_{4}$ and $\mathrm{Zn}$ $\mathrm{Cu}$ isoleusinate supplementation as a strategy to mitigate methane gas production. Earth Enviroment Science, 454.

Hambakodu, M, A Kaka, and YT Ina. 2020. Kajian in vitro kecernaan fraksi serat hijauan tropis pada media cairan rumen kambing. Jurnal IImu dan Teknologi Peternakan Tropis 7(1): 29 - 34. (In Indonesia with abstract in English)

Hilal, EY, MAE Elkhairey, and AOA Osman. 2016. The role of zinc, manganse and copper in rumen metabolism and immune function: A review article. Open Journal of Animal Science 6(4).

Hosseini-Vardanjani, SF, J Rezaei, S Karimi-Dehkordi, and $Y$ Rouzbehan. 2020. Effect of feeding nanoZnO on performance, rumen fermentation, leukocytes, antioxidant capacity, blood serum enzymes and minerals of ewes. Small Ruminant Research 191: 1 - 8.

Hungate, RE. 1966. The rumen and its microbes. Academic Press, New York and London. 544 pages.

Imanda, S, Y Effendi, Sihono, and I Sugoro. 2016. Evaluasi in vitro silase Sinambung sorgum varietas Samurai 2 yang mengandung probiotik BIOS K2 dalam cairan rumen kerbau. Jurnal IImiah Aplikasi Isotop dan Radiasi, 12(1): 1 - 12. (In Indonesia with abstract in English)

Krisnan, RB Haryanto, and KG Wiryawan. 2009. Pengaruh kombinasi penggunaan probiotik mikroba rumen dengan supplemen katalitik dalam pakan terhadap kecernaan dan karakteristik rumen domba. Jurnal IImu Ternak dan eteriner, 14(4): 262 - 269. (In Indonesia with abstract in English)

Mallaki, M, MA Norouzian, and AA Khadem. 2015. Effect of organic zinc supplementation on growth, nutrient utilization and plasma zinc status in lambs. Turk. J. Vet. Anim. Sci. 39 : 75 80.

Muktiani, A, N Arifah, and Widiyanto 2019. Influence of different vegetable oils on in vitro ruminal fermentability and nutrient digestibility in Ettawah Crossbred Goat. Animal Production 21(1): $22-29$.

Muktiani, A, and WD Prastiwi. 2014. Correlation protein and amino acid content in feed ingredients with zinc binding protein. Animal Production 16(2): $114-120$.

Noziére, P, I Ortigues-Marty, C Loncke, and D Sauvant. 2010. Carbohydrate quantitative digestion and absorption in ruminants: from feed starch and fiber to nutrients available for tissues. The International Journal of Animal Biosciences, 4(7): 1057 - 1074.

NRC (National Research Council). 1981. Nutrient requirements of goats: angora, dairy and meat goats in temperate and tropical countries. National Academy Press: USA.

Ørskov, ER, and M Ryle. 1990. Energy Nutrition in Ruminants. Elsevier Science Publishers Ltd., London. 
Pathak, AK. 2008. Various factors affecting the microbial protein synthesis in the rumen. Veterinary World, 6: 186-189.

Petrič, D, D Mravčáková, K Kucková, S Kišidayová, A Cieslak, M Szumacher-Strabel, H Huang, P Kolodziejski, A Lukomska, S Slusarczyk, K Čobanová, and Z Váradyová. 2021. Impact of zinc and/or herbal mixture on ruminal fermentation, microbiota, and histopathology in lambs. Front. Vet. Sci., 8

Putra, S. 2006. Perbaikan mutu pakan yang disuplementasi seng asetat dalam upaya meningkatkan populasi bakteri dan protein mikroba didalam rumen, kecernaan bahan kering dan nutrien ransum sapi Bali bunting. Majalah Ilmiah Peternakan, 9(1). (In Indonesia with abstract in English)

Purbowati, E, E Rianto, WS Dilaga, CMS Lestari, and R Adiwinarti. 2014. Karakteristik cairan rumen, jenis, dan jumlah mikrobia dalam rumen sapi Jawa dan Peranakan Ongole. Buletin Peternakan, 38(1): $21-26$.

Puastuti, W, D Yulistiani, IW Mathius, F Giyai, and E Dihansih. 2010. Ransum berbasis kulit buahkakao yang disuplementasi $\mathrm{Zn}$ organik: respon pertumbuhan pada domba. Jurnal Ilmu Ternak dan Veteriner 15(4): $269-277$.

Puniya, AK, R Singh, and DN Kamra. 2015. Rumen microbiology: From evolution to revolution. $P$. K.Choudhury, A. Z. M. Salem, R. Jena, S. Kumar, R. Singh and A. K. Puniya (Ed). Springer. New Delhi, India. Pp: $3-16$.

Ransa, CP, RAV Tuturoong, AF Pendong, and MR Waani. 2020. Kecernaan NDF dan ADF pakan lengkap berbasis tebon jagung pada sapi $\mathrm{FH}$. Jurnal Zootek, 40(2): 542 - 551. (In Indonesia with abstract in English)

Rahayu, RI, A Subrata, and J Achmadi. 2018. Fermentabilitas ruminal in vitro pada pakan berbasis jerami padi amoniasi dengan suplementasi tepung bongkol pisal dan molases. Jurnal Peternaan Indonesia 20(3) : 166 - 174. (In Indonesia with abstract in English)

Steel, RGD, and JH Torrie. 1994. Prinsip dan Prosedur Statistika Suatu Pendekatan Biometrik. Cetakan kedua. Translate by: B. Sumantri. Gramedia Pustaka Utama, Jakarta.

Suhada, AT, E Pangestu, and LK Nuswantara. 2012.
Kelarutan mineral $\mathrm{Ca}$ dan $\mathrm{Zn}$ hasil samping agroindustri pada kambing Jawarandu secara In Sacco. Animal Agriculture Journal, 1(1): 757 775. (In Indonesia with abstract in English)

Suhendra, D, GT Anggiati, S Sarah, AF Nasrullah, A Thimoty, and DWC Utama. 2015. Tampilan kualitas susu sapi perah akibat imbangan konsentrat dan hijauan yang berbeda. Jurnal Ilmu-Ilmu Peternakan, 25(1) : 42 - 46. (In Indonesia with abstract in English)

Supriyati, D Yulistiani, E Wina, H Hamid, and B Haryanto. 2000. Pengaruh suplementasi Zn, Cu dan Moanorganik dan organik terhadap kecernaan rumput secara in vitro. Jurnal IImu Ternak dan Veteriner 5(1): 276 - 278. (In Indonesia with abstract in English)

Susilo, E, LK Nuswantara, and E Pangestu. 2019. Evaluasi bahan pakan hasil samping industri pertanian berdasarkan parameter fermentabilitas ruminal secara in vitro. Jurnal Sain Peternakan Indonesia, 14(2): 128 - 136. (In Indonesia with abstract in English)

Tilley, JMA, and RA Terry. 1963. A two stage technique for in vitro digestion of forage crops. Journal British Grassland Society 18: $104-111$.

Widodo, F Wahyono, and Sutrisno. 2012. Kecernaan bahan kering, kecernaan bahan organik, produksi VFA dan $\mathrm{NH}_{3}$ pakan komplit dengan level jerami padi berbeda secara in vitro. Animal Agricultural Journal, 1(1): 215 - 230. (In Indonesia with abstract in English)

Wang, RL, JG Liang, Lin Lu, Li Y Zhang, Su F Li, and Xu $G$ Luo. 2013. Effect of zinc Source on performance, zinc status, immune response and rumen fermentation of lactating cows. Biological Trace Element Research, 152: 16 - 24.

Wahyuni, IMD, A Muktiani, and M Christiyanto. 2014. Kecernaan bahan kering dan bahan organic dan degradibilitas serat pada pakan yang disuplementasi tanin dan saponin. Jurnal Agripet 2(2): 115 -124. (In Indonesia with abstract in English)

Yurleni, R Priyanto, E Gunardi, and KG Wiryawan. 2013. Efektivitas minyak ikan Lemuru terproteksi terhadap populasi mikrob rumen dan fermentasinya pada kerbau dan sapi. Jurnal Verteriner 14(3): 285 - 293. (In Indonesia with abstract in English) 